\title{
Table of Contents
}

Copyright References — VII

Thorsten Fögen \& Richard Warren

Graeco-Roman Antiquity and the Idea of Nationalism in the

Nineteenth Century: Introduction -1

Anthony D. Smith

Classical Ideals and the Formation of Modern Nations in Europe -19

Athena S. Leoussi

Making Nations in the Image of Greece: Classical Greek Conceptions of the Body in the Construction of National Identity in Nineteenth-Century England, France and Germany - 45

Tim Rood

'Je viens comme Thémistocle': Napoleon and National Identity after

Waterloo - 71

Edmund Richardson

The Emperor's Caesar: Napoleon III, Karl Marx and the History of Julius Caesar - 113

Rosemary Barrow

Faithful unto Death: Militarism, Masculinity and National Identity in Victorian Britain — 131

Richard Hingley

Constructing the Nation and Empire: Victorian and Edwardian Images of the Building of Roman Fortifications - 153

Richard Warren

Henry Courteney Selous' Boadicea and the Westminster Cartoon

Competition - 175

Christopher B. Krebs

A Nation Finds its People: Friedrich Kohlrausch, New Readers and Readings of Tacitus' Germania and the Rise of a Popular German Nationalism — 199 
VI _ Table of Contents

Michael Sommer

Hermann the German: Nineteenth-Century Monuments and Histories - 219

Richard Warren

Arminius in Bohemia: Two Uses of Tacitus in Czech Art - 235

Laurie O’Higgins

Classical Translations and Strands of Irish Nationalism - 269

Contributors -289

Index rerum -293

Index nominum (personarum) 299

Index locorum -305 